\title{
Assessment of Reinforced Concrete Building for Disaster Reduction Strategy in Padang City, West Sumatra, Indonesia
}

\author{
Eka Juliafad ${ }^{1,2}$, Annisa Prita Melinda ${ }^{2}$ \\ ${ }^{1}$ The University of Tokyo, IIS,Komaba 4-6-1, Tokyo, Japan \\ ${ }^{2}$ Universitas Negeri Padang, Jl.Prof.Hamka, Padang, Indonesia
}

\begin{abstract}
Padang City, West Sumatra province is one of the most vulnerable cities in the west coast of Indonesia. Together with the increase in population in Padang City, the number of the building is also increasing. Meanwhile, researchers predicted that Padang City is facing the impendence of mega-earthquake with magnitude more than 8 in scale Richter (SR). The last Earthquake with magnitude 7.6 SR caused fatality with more than 1200 people died and almost 3000 others were injured. Most of the victims injured due to the collapse and damage of buildings, especially the Reinforced Concrete (RC) structure. To reduce the damage due to seismic load as the preparation for the future earthquake, the assessment of the element at risk subjected to the seismic load in Padang City is essential. The predominant building typology in Padang City is RC building. Using the Applied Element Method that can show structural response till collapse state, has been simulated typical low-rise RC infilled wall building in Padang City with the consideration of its different on concrete quality based on local concreting workmanship. Incremental Dynamic Analysis (IDA) by using some ground motion has been used to observe the structural response. The damage states and damage pattern has been judged based on HAZUS criteria. The results show that local compaction method affected the concrete compression quality, that also influences the building performance which is subjected to earthquake loads.
\end{abstract}

Keywords: Seismic Load, Reinforced Concrete Building, Applied Element Method, Concreting Workmanship, Building Assessment, Disaster Reduction.

\section{Introduction}

\subsection{The vulnerability of Infill Masonry RC Building}

The earthquake damage records in the last decade, show that Reinforced Concrete (RC) building with infill masonry wall suffered many variations of damage, started from slightly damaged till collapse state (e.g., L’Aquila 2009 (Ricci et al.2010), Lorca 2011 (Cabanas et.al.2011) [1][2]

The vulnerability of RC building is a contribution of the uncertainty of concrete execution, high irregularity due to the arrangement of a masonry wall, and the brittle behavior of brick wall material.

However, the number of RC building structure keep growing due to the locally available material and labor skill. Especially in the urban area, the population of RC building with infill wall follows the positive trend of its population.

Hence, if the concrete execution is not adequate, a massive number of $\mathrm{RC}$ building in a populated urban area will affect the increasing of the fatality due to earthquake hazards.

Observation of building damages due to $30^{\text {th }}$ September 2009 in Padang City West Sumatra, shows that the performance of RC buildings with infill wall was very varied, with damage ranging from minor to total collapse. Majority of buildings suffered significant cracking in masonry infill, and out of plan failure are often observed. The failure due to the development of a plastic hinge at the top and bottoms of the column were majorly found [3].

\subsection{Concrete Quality in Indonesia}

Concrete structures are unique compared to structures made from other material since its actual quality is determined through the execution of the actual construction site.

The observation found some concrete defects in concrete structures in Padang City, Indonesia [4][5]. Most defects found is honeycombing which is caused by improper compaction work and curing of placed concrete.

Proper compaction ensures the proper shield around the reinforcement and tendons and helps to achieve the higher ultimate strength, abrasion resistance and improves the bond strength between the reinforcement and concrete [6], [7].

Juliafad et al. observed and interviewed 100 builders in the study area and found that the concreting workmanship conducted by local builders seem to be inadequate. The builders mainly used rodding and hammering method to compact the concrete. Meanwhile, some percentage of the builders answered they do not compact the concrete. Some others answered they added more water to increase the workability of the placed concrete [8].

This finding indicated the poor concreting workmanship which can reduce the concrete strength.

\footnotetext{
* Corresponding author: eka-j@iis.u-tokyo.ac.jp
} 
The facts above motivated this research to conduct an assessment of RC buildings in Padang City due to earthquake loads based on local concrete compaction method

\section{Research Objective}

This research is aimed at assessment and analyzes the masonry infill RC buildings in the earthquake-prone area, Padang City, Indonesia which based on the actual data from existing RC buildings. The measurement and detail cross section were obtained and used to build a numerical model of selected buildings.

The reduction of concrete strength due to local compaction method was addressed as the parameters that influence the overall performance of the buildings.

\section{Research Methodology}

After conducted a literature review and found the predominant local compaction method, the compression strength of concretes was determined. Each concrete strength based on compaction methods was used as the input concrete material for the structural model. The structural model was developed consdering the actual data from existing masonry infill RC Buildings in Padang City. After selected strong ground motion records based on its magnitude, frequency, and its duration, the Incremental Dynamic Analysis (IDA) was conducted by using the Applied Element Method (AEM). Damage patterns based on HAZUS damage criteria were used to judge the damage level of selected buildings.

Figure 1 shows the research methodology flowchart :

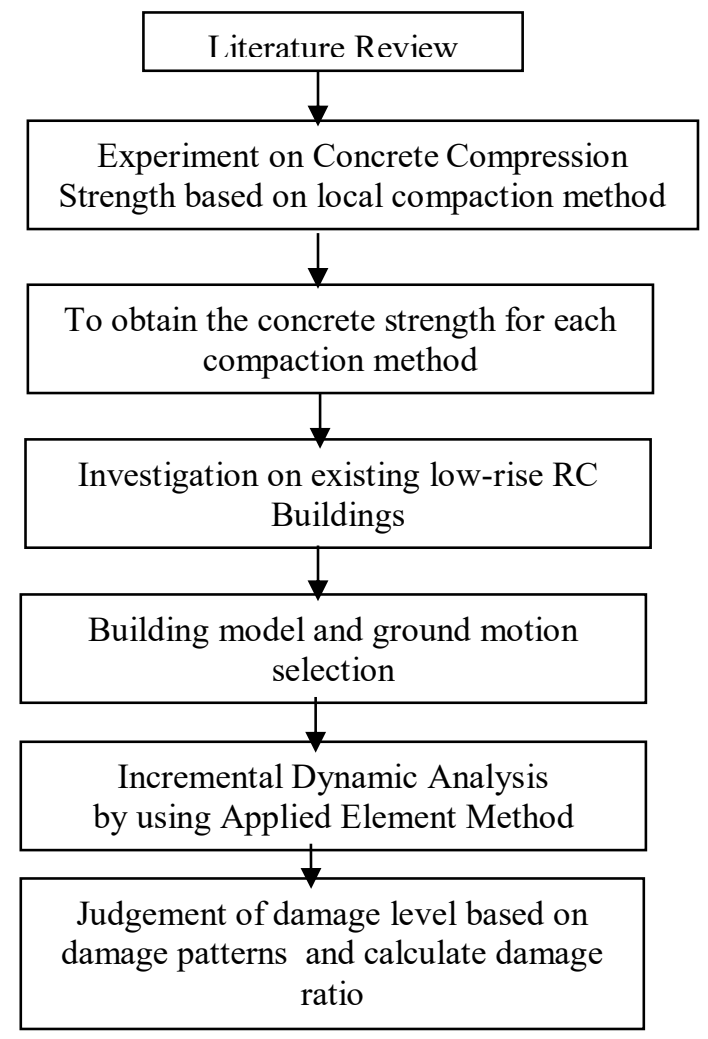

Figure 1. The flowchart of Research Methodology

\section{Effect of Local Compaction Method to Concrete Strength}

4.1. The experiment of Local Compaction Method on Concrete by using local material.

As mentioned before, there are three local compaction methods conducted by local builders in Padang City, by using a vibrator, rodding and hummer [8].

Each compaction methods were applied to fresh concrete mix contained available local materials e,g - aggregates and cement. Concrete mix design was based on the recommendation from Public Work Department of Indonesia which is one portion of cement, two portions of fine aggregate, three portions of coarse aggregate. The water-cement ratio is $0.5(50 \%)$ of the cement portion. The mix design method uses the volume based method.

Figure 2 shows the experimental of each compaction method.

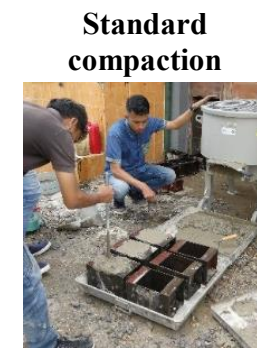

(a)

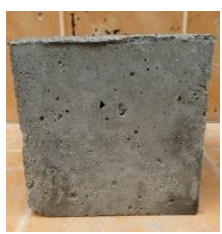

(d)

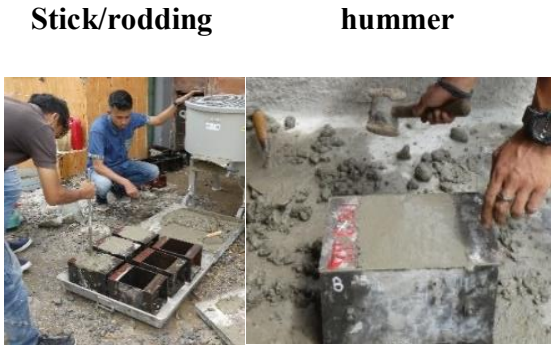

(b)

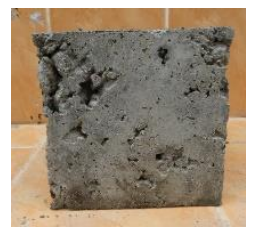

(e) (c)

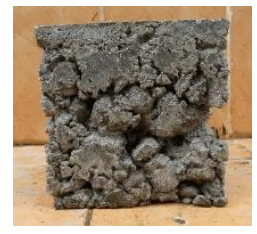

(f)
Figure 2. The experiment of Local Compaction Method on Concrete Cube

Figure 2.a shows the compaction method uses standard compaction method to simulate the vibration method. Considering the size of vibrator needle which might overcompacted the placed concrete on the cube, the vibrator method is simulated by compacting concrete as standard compaction in Indonesia Building Code for Concrete mix. This compaction was conducted with the assumption that the concrete does not suffer over-compaction and correctly vibrate.

Figure 2.b.and c shows the compaction method uses rodding and hummer. 10 cube molds were rodded, and other 10 molds were hitting using hummer for 15 times. The frequency of compaction was based on the information from the builders [8].

\subsection{Concrete Strength based on Compaction Method}

Figure 2.e, 2.f, and 2.g show the visual of concrete cube based on standard compaction, rodding compaction and hummer compaction method consequently. The figures show the difference in the appearance of the hardened concrete cube. The concrete with standard method shows 
a good appearance and minimum porosity. The concrete with rodding compaction shows honeycombing effects, and the last one figure 2.f, with hummer compaction, shows very significant porosity or honeycombing effects To get the strength of each concrete cube, we conducted a compression test based on Indonesia National Standard for Concrete Compression test.

Figure 3 shows the results of the average value if the concrete compression test which is affected by a local concrete compaction method.

Concrete cube with standard compaction which represents the vibrator method show the highest strength; $18.76 \mathrm{MPa}$, while the concrete strength with rodding method (using a stick) is reduced by $14 \%$. The lowest strength is obtained if we use hummer for compaction method. The use of hummer to compact the placed concrete decreased the concrete strength to $30 \%$ fc' using standard compaction.

Effect of Local Compaction Methods to Concrete Strength [MPa]

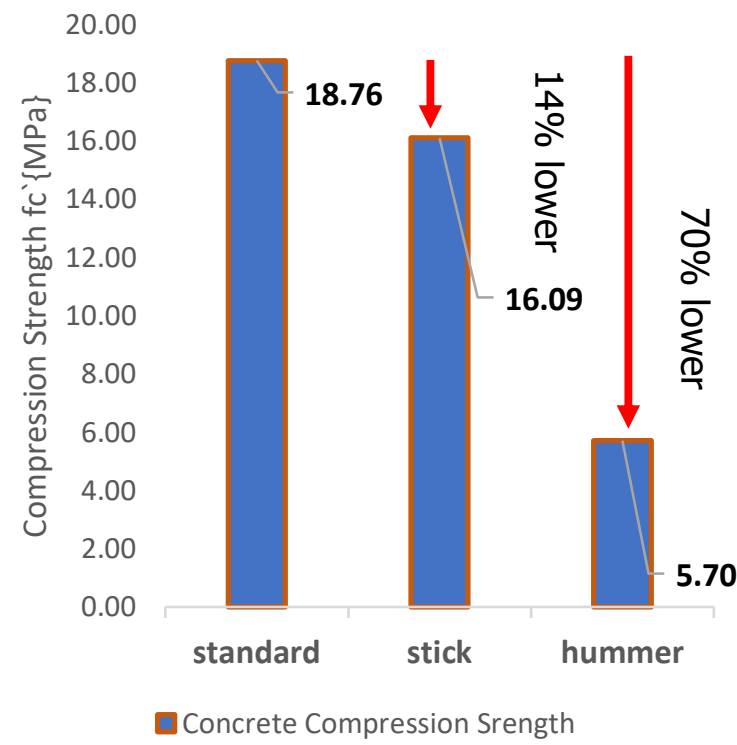

Figure 3. Effect of Local Compaction Methods to Concrete Strength

The reduction of concrete strength probably due to the increase of porosity of concrete (see Figure 2.d, 2e, and $2 \mathrm{f}$ ). The effects of improper compaction on the strength and porosity of concrete were studied by Suleiman and Kevern (2003) as shown in Figure 4[17].

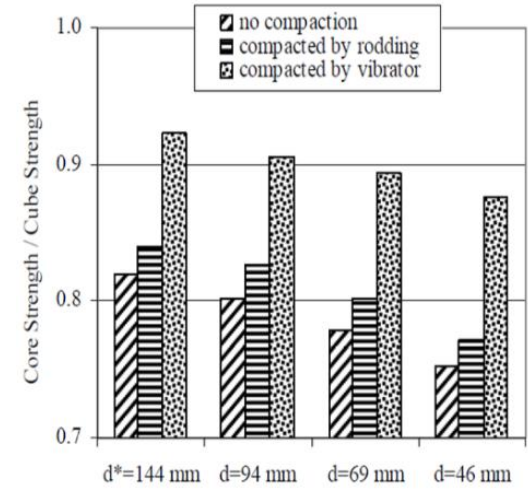

Figure 4: Effects of compaction [11]
The results in Figure 3 for rodding compaction method shows the same affect with research conducted by Tuncan [9] as can be seen in Figure 5. However, this research can show one local compaction method that might be yet demonstrated by previous researchers, which is using hummer as external compaction.

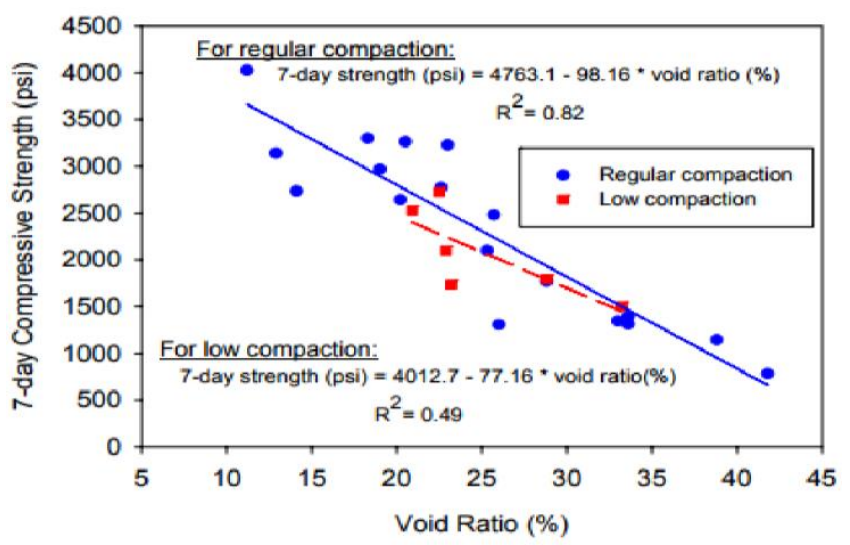

Figure 5: Effect of improper compaction on concrete strength [9]

\section{Incremental Dynamic Analysis}

Incremental Dynamic Analysis (IDA) is a method to perform a series of nonlinear dynamic analysis of a structural model for multiple records by scaling each record to several levels of intensity that are selected to uncover the full range of model behavior ; from elastic to yielding and nonlinear elastic, finally leading to global dynamic stability (Dimitros Vamvatsikos, 2005) [10][11] Each analysis can be characterized by at least two parameters, an Intensity Measure (IM) and a Damage Parameter (DM). In this study, the IM is presented by Peak Ground Acceleration, and DM use damage patterns and damage level.

\section{Applied Element Method}

Applied Element Method (AEM) is a developed method of structural analysis which can follow the structural behavior of a structural model from elastic range, crack initiation and propagation, separation of structural elements till total collapse in reasonable CPU time with reliable accuracy [12][13].

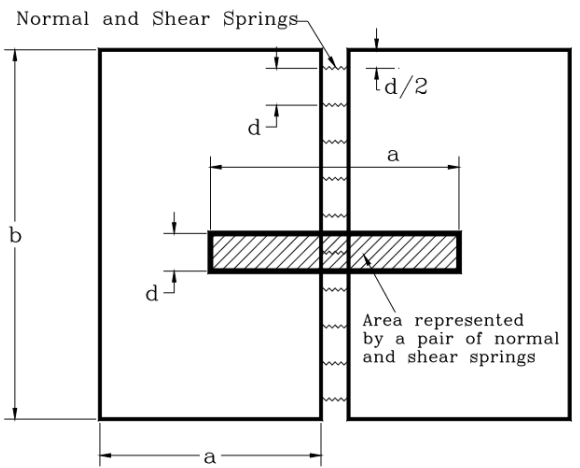

Figure 6. Distribution of springs and area of influence of each pair of springs in AEM 


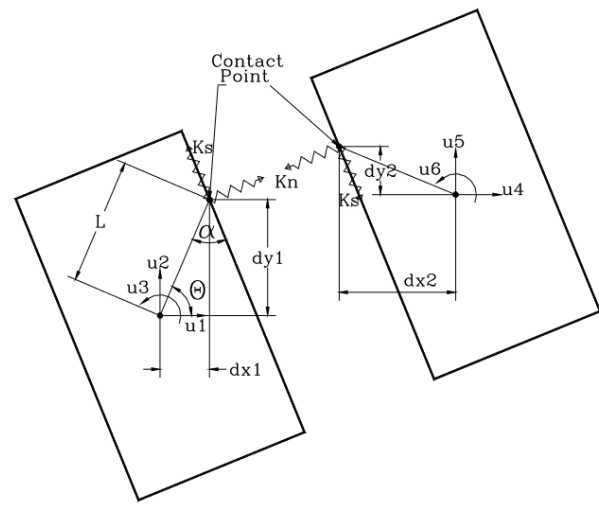

Figure 7. Element Shape, contact point and degrees of freedom

The two elements shown in Fig.6 are assumed to be connected by pairs of normal and shear springs located at contact points which are distributed around the element edges. Each pair of springs represents the stresses and deformations of a specific area of the studied elements.

$$
\begin{aligned}
& \left.K_{n}=\frac{E^{*} d^{*} T}{a} \text { and } K_{s}=\frac{G * d^{*} T}{a} \ldots \ldots 1\right) \\
& {\left[K_{G}\right][\Delta]=[F]} \\
& F_{q}=\sum_{i=1}^{N} K_{q i} * \Delta_{i}
\end{aligned}
$$

Spring of each element is defined in Eq.1 where $d$ is the springs distance, $\mathrm{T}$ is the thickness of the element, and "a" representative area's length, E, and G are the Young's and shear modulus of the material, respectively. The previous equation indicates that each spring represents the stiffness of an area $\left(d^{*} T\right)$ with length "a" of the studied material. In the case of reinforcement, this area is replaced by that of the reinforcement bar.

The global stiffness matrix KG for load and displacement control is mentioned in eq. 2 , and the applied load can be calculated by using equation 3 .

For further explanation are provided in Tagel and Meguro [12], [13].

\section{Investigation of Existing RC Buildings}

Actual investigation of existing $\mathrm{RC}$ buildings with masonry wall was conducted in Padang City, Indonesia in December 2017. The target building is the low storey building with 1 or 2 stories. This type of building is the predominant $\mathrm{RC}$ building in Padang City [5].

This investigation involved the main parameters that necessary to build the structural model of target buildings. Table 2 shows the obtained parameters and the tools that were used in this building investigation.
Table 1. Measured Parameters of Existing RC Buildings Investigation

\begin{tabular}{|l|l|l|l|}
\hline No & Parameters & Sub-parameter & Tools \\
\hline 1 & Dimension & $\begin{array}{l}\text { Building layout; } \\
\text { vertical and } \\
\text { horizontal }\end{array}$ & $\begin{array}{l}\text { Laser } \\
\text { measurement }\end{array}$ \\
\cline { 3 - 4 } & $\begin{array}{l}\text { Structural Element; } \\
\text { column, beam, } \\
\text { opening, wall }\end{array}$ & $\begin{array}{l}\text { Laser } \\
\text { measurement } \\
\text { or } \\
\text { measurement } \\
\text { tape }\end{array}$ \\
\hline 2 & $\begin{array}{l}\text { Element } \\
\text { Cross } \\
\text { Section }\end{array}$ & $\begin{array}{l}\text { The dimension of } \\
\text { column, beam, and } \\
\text { slab }\end{array}$ & $\begin{array}{l}\text { Measurement } \\
\text { tape }\end{array}$ \\
\cline { 3 - 5 } & Concrete Cover & Rebar Locator \\
\cline { 3 - 5 } & $\begin{array}{l}\text { Main reinforcemnet } \\
\text { arrangement }\end{array}$ & Rebar Locator \\
\cline { 3 - 5 } & Stirrups space of & Rebar Locator \\
\cline { 3 - 5 } & $\begin{array}{l}\text { Diameter } \\
\text { reinforcement }\end{array}$ & $\begin{array}{l}\text { Wall confinement } \\
\text { existence especially } \\
\text { above the wide } \\
\text { opening }\end{array}$ & Rebar Locator \\
\hline 3 & $\begin{array}{l}\text { Additional } \\
\text { Confineme } \\
\text { nt }\end{array}$ & \multicolumn{3}{|l}{} \\
\hline
\end{tabular}

The figure shows some activities that were explained in the table above.

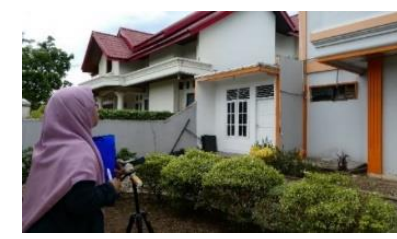

Figure 8. Building Height Measurement

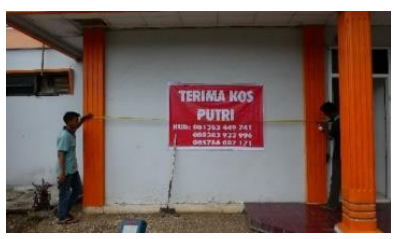

Figure 9. Building Layout Measurement
Figure 8 and 9 show the measurement of building height using laser measurement and the horizontal layout by measuring the distance between column by using tape measurement.

To identify the cross-section of the structural element, we measured column dimension and reinforcement position and its range both main reinforcement and stirrups. Rebar locator was used in this study. To measure the actual diameter of the steel bars, we found some part of the column and beam that are not plastered. Figure 10 and 11. show the cross section investigation and steel diameter measurement.
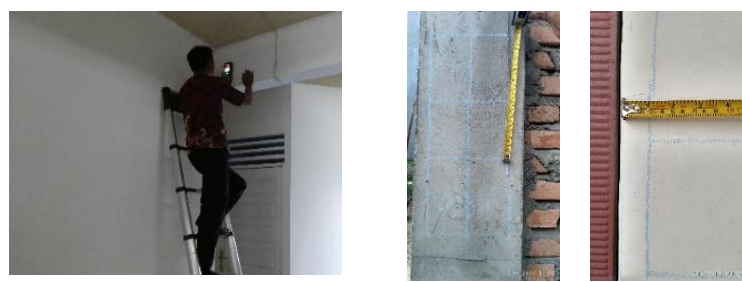

Figure 10. Rebar Scanning Proces 

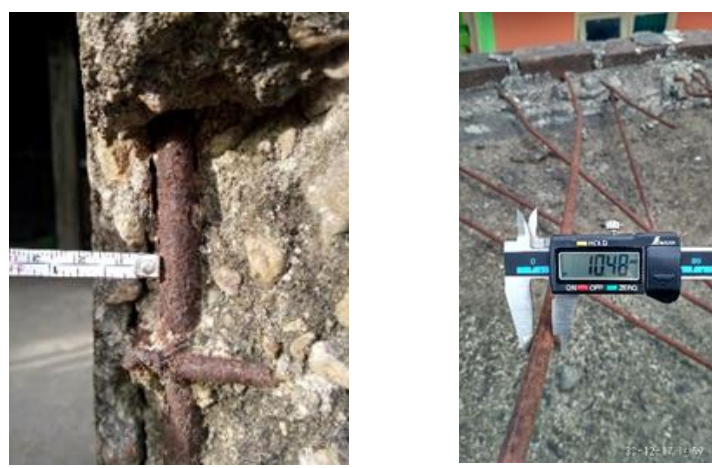

Figure 11. Steel Diameter Measurement

\section{Selected Buildings Types and Ground Motions \\ 8.1.Geometry and Material}

From a database of investigation of existing RC buildings in Padang City, some buildings were selected.

Figure 12 show one of the selected RC Buildings and its parameter.
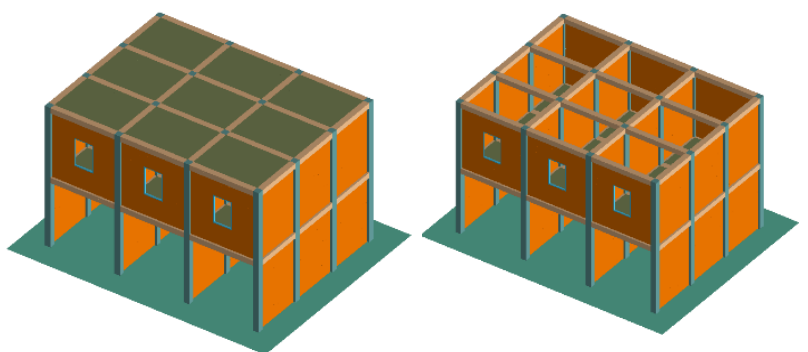

Figure 12. A sample of the 3D model of Selected RC Building

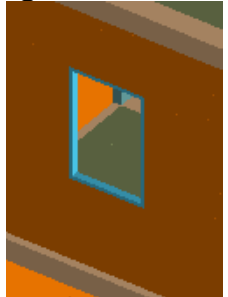

Figure 13. 8 nodes element for opening frame

\begin{tabular}{|l|c|c|c|}
\hline Cross Section & Column & Beam & Slab \\
\hline Dimension $(\mathrm{mm})$ & $330 \times 330$ & $330 \times 300$ & 140 \\
\hline Longitudinal Steel & $4 \mathrm{P} 12 ; 2 \mathrm{P} 12$ & $3 \mathrm{P} 12 ; 2 \mathrm{P} 12$ & $\mathrm{P} 10-100$ \\
\hline Stirrups & $\mathrm{P} 8-100$ & $\mathrm{P} 8-100$ & \\
\hline Actual diameters $(\mathrm{mm})$ & 11.83 & 11.52 & 10.48 \\
\hline $\mathrm{fc}^{\prime}[\mathrm{MPa}]$ & 17 & 17 & 17 \\
\hline $\mathrm{fy}[\mathrm{kg} / \mathrm{mm} 2]$ & 33.62 & 33.62 & 47.55 \\
\hline $\mathrm{fu} / \mathrm{fy}$ & 1.24 & 1.24 & 0.68 \\
\hline
\end{tabular}

A numerical model was developed using AEM, and each material data was assigned. However, since the rebar location at joint corner is difficult to be scanned, in this model, the reinforcement in the joint corner was assumed to meet the building code.

\subsection{Earthquake Loading}

The numerical models were subjected to real ground motion record. In this study, we selected El-Centro and Kobe earthquake, due to its magnitude, duration, and the recorded building damage [14]

Each ground motion was scaled to lower intensity and to higher intensity to observe building performance step by step. Figure 14 and 15. show Elcentro and Kobe ground motion records.

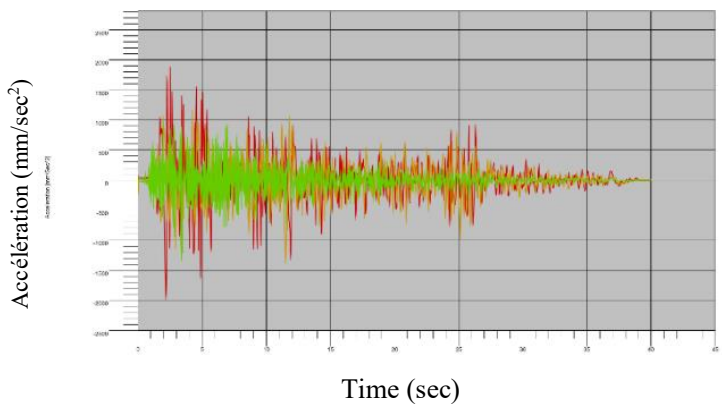

Figure 14. Peak Ground Acceleration of Elcentro Earthquake

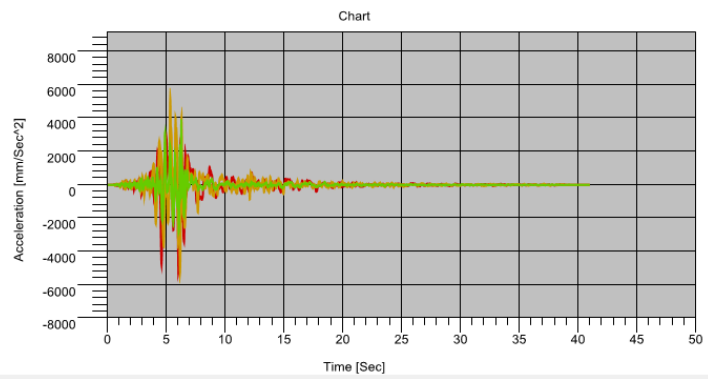

Figure 15. Peak Ground Acceleration of Kobe Earthquake

\section{Results of Numerical Simulation of Low-Rise Infill Masonry Building in Padang City}

Figure 16-18 shows that damage patterns of the selected RC Buildings model for each scaled elcentro ground motion started from $0.1 \mathrm{~g}, 0.2 \mathrm{~g}, 0,3 \mathrm{~g}$, and $0,4 \mathrm{~g}$, till collapse. The judgment for damage level used HAZUS damage criteria [15].

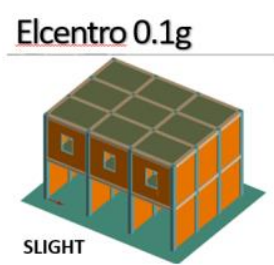

Elcentro 0.6g

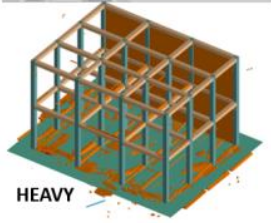

Figure 16. Damage Patterns of RC building no.62 for target ground motion increments

Figure 16 shows the damage patterns and collapse behavior of typical 2 storey buildings which commonly find in Padang City. This type of building usually uses as 
hybrid buildings, where the 1st storey is used for shop, and the $2^{\text {nd }}$ storey might be used for residential, or office. As we can see from the collapse behavior, the soft storey effect caused the collapse of the building. This behavior also found in many buildings in the last September 2009 Earthquake.
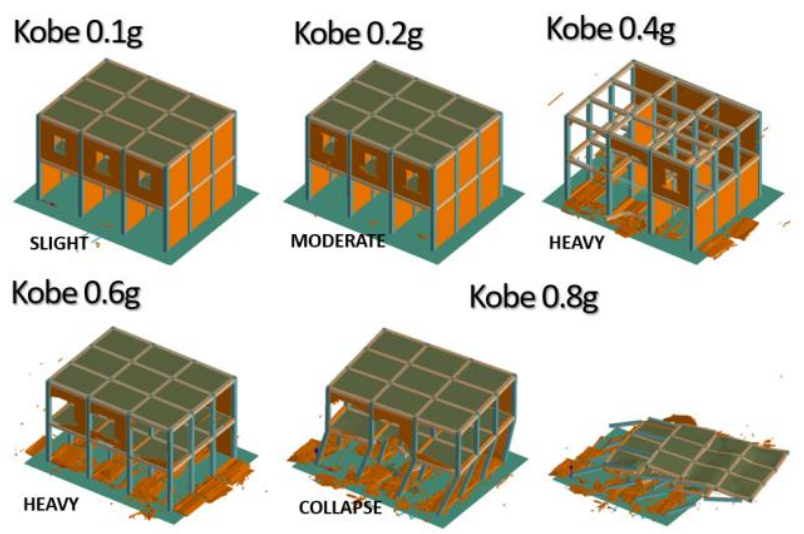

Figure 17. Damage Patterns of RC Building Type no 62 which subjected to Kobe DM increments

Figure 17 shows the damage patterns of the same type of buildings as shown in Fig.18. However, the lower magnitude and shorter duration of the Kobe earthquake gave the opportunity for the building to stand longer. However, the same damage patterns as the Elcentro earthquake can be seen, such as out of plan damage at infill wall and soft storey effects.

Figure 18 shows another type of RC building. The characteristic of this model is its overhang in front of the building. Compare to the previous model; the overhang structure caused the earlier severe or extensive damage to the building.

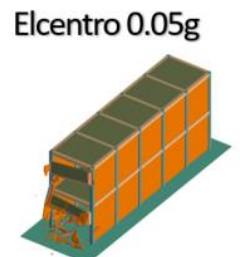

Elcentro $0.4 \mathrm{~g}$

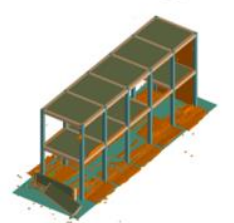

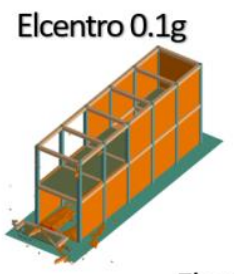

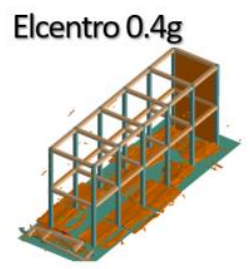

Elcentro $0.8 \mathrm{~g}$

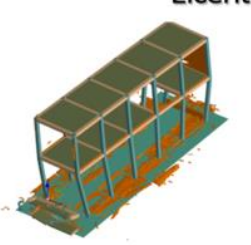

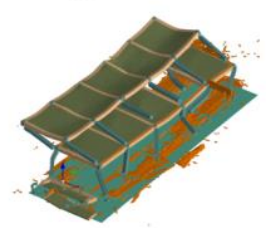

Figure 18. Damage Patterns of RC Building Type 58 subjected to Elcentro DM

The comparison of building behavior which is affected by the strength of the concrete is shown in Table 2. As aforementioned, the reduction is assumed based on the local compaction method influence on the concrete strength. In Table 2, we can see, overall, the collapsed state of the structure is influenced by the concrete strength level, notably when the strong earthquake subjected to the building, e.g., Elcentro earthquake.
If we relate the differences of building damage level for each concrete strength to the compaction method, the practice to use hummer for external vibration only that can be found as a common practice in the construction field especially low story building will reduce the RC building capacity to resist earthquake load significantly.

Table 2. Comparison of Selected RC Building Type damage level based on concrete compression strength based on reduction due to compaction method

\begin{tabular}{|c|l|c|c|c|c|c|c|c|c|c|}
\hline $\begin{array}{c}\text { fc } \\
\text { [MPa] }\end{array}$ & $\begin{array}{l}\text { Ground } \\
\text { Motion }\end{array}$ & \multicolumn{10}{|c|}{ Damage Level } \\
\hline 17 & Elcentro & N & S & E & E & C & C & C & C & C \\
\hline 11.3 & Elcentro & S & E & E & E & C & C & C & C & C \\
\hline 5 & Elcentro & S & M & C & C & C & C & C & C & C \\
\hline 17 & Kobe & N & S & M & M & E & E & E & E & C \\
\hline 11.3 & Kobe & S & M & E & E & E & E & E & E & C \\
\hline
\end{tabular}

$\mathrm{N}$ : No Damage

S: Slight damage

M: Moderate Damage

E: Extensive Damage

$\mathrm{C}$ : Collapse

After calculating the actual damage probability for each building with different concrete strength, the probability of damage and collapse due to local compaction practice is presented in table 3 and 4 below. The yellow color shows the boundaries of excedeed damage level (None, Slight, Moderate, Extensive, Collapse) for each earthquake intensity $(0.05,0.1$, till $1.2 \mathrm{~g})$

The effect of hummer compaction practice clearly influences the damage probability for each damage level. For example, the building with hummer compaction practice (see Table 4), reaches collapse level at $0.8 \mathrm{~g}$ which is faster than the standard compaction method which reached collapse level at $1.1 \mathrm{~g}$ (see Table 3 ).s

Table 3. Comparison of Selected RC Building Type damage probability based on standard compaction method

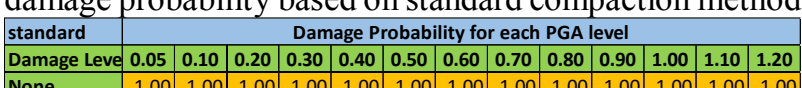
\begin{tabular}{|l|c|c|c|c|c|c|c|c|c|c|c|c|c|c|}
\hline None & 1.00 & 1.00 & 1.00 & 1.00 & 1.00 & 1.00 & 1.00 & 1.00 & 1.00 & 1.00 & 1.00 & 1.00 & 1.00 \\
\hline
\end{tabular} \begin{tabular}{|l|l|l|l|l|l|l|l|l|l|l|l|l|l|l|l|}
\hline Slight & 0.67 & 1.00 & 1.00 & 1.00 & 1.00 & 1.00 & 1.00 & 1.00 & 1.00 & 1.00 & 1.00 & 1.00 & 1.00 \\
\hline
\end{tabular} \begin{tabular}{|l|l|l|l|l|l|l|l|l|l|l|l|l|l|}
\hline Moderate & 0.33 & 0.67 & 1.00 & 1.00 & 1.00 & 1.00 & 1.00 & 1.00 & 1.00 & 1.00 & 1.00 & 1.00 & 1.00 \\
\hline Elight
\end{tabular}

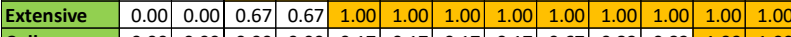
\begin{tabular}{|l|l|l|l|l|l|l|l|l|l|l|l|l|l|}
\hline Collapse & 0.00 & 0.00 & 0.00 & 0.00 & 0.17 & 0.17 & 0.17 & 0.17 & 0.67 & 0.83 & 0.83 & 1.00 & 1.00 \\
\hline
\end{tabular}

Table 4. Comparison of Selected RC Building Type damage probability based on hummer compaction method \begin{tabular}{|l|c|c|c|c|c|c|c|c|c|c|c|c|c|}
\hline hummer & \multicolumn{10}{c|}{ Damage Probability for each PGA level } \\
\hline Damage Leve & $\mathbf{0 . 0 5}$ & $\mathbf{0 . 1 0}$ & $\mathbf{0 . 2 0}$ & $\mathbf{0 . 3 0}$ & $\mathbf{0 . 4 0}$ & $\mathbf{0 . 5 0}$ & $\mathbf{0 . 6 0}$ & $\mathbf{0 . 7 0}$ & $\mathbf{0 . 8 0}$ & $\mathbf{0 . 9 0}$ & $\mathbf{1 . 0 0}$ & $\mathbf{1 . 1 0}$ & $\mathbf{1 . 2 0}$ \\
\hline None & 1.00 & 1.00 & 1.00 & 1.00 & 1.00 & 1.00 & 1.00 & 1.00 & 1.00 & 1.00 & 1.00 & 1.00 & 1.00 \\
\hline Slight & 1.00 & 1.00 & 1.00 & 1.00 & 1.00 & 1.00 & 1.00 & 1.00 & 1.00 & 1.00 & 1.00 & 1.00 & 1.00 \\
\hline Moderate & 0.67 & 1.00 & 1.00 & 1.00 & 1.00 & 1.00 & 1.00 & 1.00 & 1.00 & 1.00 & 1.00 & 1.00 & 1.00 \\
\hline Extensive & 0.00 & 0.67 & 1.00 & 1.00 & 1.00 & 1.00 & 1.00 & 1.00 & 1.00 & 1.00 & 1.00 & 1.00 & 1.00 \\
\hline Collapse & 0.00 & 0.00 & 0.17 & 0.17 & 0.50 & 0.67 & 0.83 & 0.83 & 1.00 & 1.00 & 1.00 & 1.00 & 1.00 \\
\hline
\end{tabular}

\section{Conclusion}

This research finds that local compaction method practice in Indonesia generally can be categorized into three methods: using a vibrator, rodding and hammering. Based on the simple experiment to simulate the compaction practice in the field, we can find that the rodding method 
does not reduce the concrete compression strength significantly. However, the hummer method does.

To understand the actual behavior of the existing typical $\mathrm{RC}$ building in the seismic prone area such as Padang City, field study to get the real parameter of RC building was conducted. The IDA and AEM method was used to analyze the selected building, which is possible to observe the building damage step by step by scaling up or scaling down the real ground motion records.

The AEM also clearly can follow the behavior of building a model from elastic to collapse state, which gives advantages to judge damage level precisely.

This research shows that the significant reduction of the concrete strength will affect the damage level of RC building. If we relate to the compaction method, the practice of using hummer to vibrate the placed concrete should be controlled by the related institution and stakeholder. Avoiding the number of fatality due to collapsed buildings is essential.

However, the number of sample of concrete and building both are needed to be improved. The significant number of building model and analysis will give a more precise prediction of the behavior of the building when subjected to a seismic load.

It is also important to be noted that the reinforcement at the joint corner is assumed to meet the building standard, which results in the building performance is better than the actual ones. So, it is necessary to analyze by modeling the weak joint corner in the future.

\section{References}

[1] C. Del Gaudio, P. Ricci, G. M. Verderame, and G. Manfredi, "Development and urban-scale application of a simplified method for seismic fragility assessment of RC buildings," Eng. Struct., vol. 91, pp. 40-57, 2015.

[2] B. BENITO and L. CABAÑAS, “An approach to the measurement of the potential structural damage of earthquake ground motions," Earthq. Eng. Struct. Dyn., vol. 26, no. February 2016, pp. 79-92, 1997.

[3] S. M. Wilkinson, J. E. Alarcon, R. Mulyani, J. Whittle, and S. C. Chian, "Observations of damage to buildings from Mw7.6 Padang earthquake of 30 September 2009," Nat. Hazards, vol. 63, no. 2, pp. 521-547, 2012.

[4] E. Juliafad et al., "SURVEY ACTIVITIES ON RESIDENTIAL BUILDING IN WEST SUMATRA, INDONESIA," 2010.

[5] JUliAFAD, E., MEGURO, K., \& GOKON, H. (2017). Study on The Environmental System towards The Development of Assessment Tools for Disaster Reduction of Reinforced Concrete Building due to Future Mega-Earthquake in Padang City, Indonesia. SEISAN KENKYU, 69(6), 351-355.

[6] M. G. Stewart, “Workmanship and its influence on probabilistic models of concrete compressive strength.pdf," no. January 1995, 2015.
[7] M. G. Stewart, “ Workmanship and its influence on probabilistic models of concrete compressive strength.pdf," no. September 2015.

[8] E. Juliafad, I. G. Rani, F. Rifwan, Y. F. P, and K. Meguro, "Concreting Workmanship in Indonesia Study Case : Padang City, West Sumatra,” 2018. (to be published)

[9] M. Tuncan, Ö. Arı̈z, K. Ramyar, B. Karasu, A. Tuncan, and K. Kilınç, "Effect of Compaction on Assessed Concrete Strength," IV. Ceram. Glas. Enamel, Glaze Pigment Semin. with Int. Particip. (SERES 2007), no. September 2017, 2007.

[10] D. Vamvatsikos and C. Allin Cornell, "Incremental dynamic analysis," Earthq. Eng. Struct. Dyn., vol. 31, no. 3, pp. 491-514, 2002.

[11] D. Vamvatsikos and C. A. Cornell, "Direct Estimation of Seismic Demand and Capacity of Multidegree-of-Freedom Systems through Incremental Dynamic Analysis of Single Degree of Freedom Approximation," J. Struct. Eng., vol. 131, no. 4, pp. 589-599, 2005.

[12] H. Tagel-Din and K. Meguro, "Analysis of a small scale RCbuilding subjected to shaking table tests using applied element method," 12 WCEE. New Zealand[sn], no. January 2000, pp. 1-8, 2000.

[13] K. Meguro and H. S. Tagel-Din, “Applied Element Method Used for Large Displacement Structural Analysis," J. Nat. Disaster Sci., vol. 24, no. 1, pp. 25-34, 2002.

[14] IDMC, “Global Estimates 2015. People displaced by disasters," pp. 1-109, 2015.

[15] F. E. M. A. FEMA, "Multi-Hazard Loss Estimation Methodology, Flood Model: HazusMH 2.1 User Manual,”p. 863, 2012.

[16] Neville, A.M., Properties of Concrete, Pitman Books Limited, London (1981)

[17] Suleiman, M. T., Kevern, J., Schaefer, V. R., and Wang, K., (2003). Effect of compaction energy on pervious concrete properties 